\title{
Response of some soil attributes to different land use types in calcareous soils with Mediterranean type climate in north-west of Iran
}

\author{
Salar Rezapour
}

Received: 13 August 2012/Accepted: 24 June 2013/Published online: 11 July 2013

(C) The Author(s) 2013. This article is published with open access at Springerlink.com

\begin{abstract}
Monitoring general variability of soil attributes is a fundamental requirement from the point of view of understanding and predicting how ecosystems yield. In order to monitor impact of different land use types on the combination of morphological, clay mineralogical and physicochemical characterizes, 42 soil samples $(0-30 \mathrm{~cm})$ were described and analyzed. Soil samples belonging to Cambisols and Vertisols reference soil groups collected from three neighboring land use types included cropland (under long-term continuous cultivation), grassland, and forestland. The soils were characterized by high $\mathrm{pH}$ (mean of 7.1-7.5) and calcium carbonate equivalent (CCE) (mean of $35-97 \mathrm{~g} \mathrm{~kg}^{-1}$ ) in the three land use types. The weakening in soil structure, hardening of consistency, and lighting of soil color occurred for the cropland under comparable condition with grassland and forest. Changes in land use types produced a remarkable change in the XRD patterns of clay minerals containing illite and smectite due the dynamic and removal of potassium. Continuous cultivation resulted in an increase in sand content up to $35 \%$ while silt and clay content decreased up to 22 and $18 \%$, respectively, as compared to the adjoining grassland and forest mainly as a result of the difference of dynamic alterational and erosional process in the different land use. Long-term cultivation caused a negative and degradative aspects on soil heath as is manifested by the increasing in soil $\mathrm{pH}$ (a rise of $0.3-0.46$ unit), electrical conductivity (EC) (a rise of 1.78-5.5 times), sodium absorption ration (SAR) (a rise of 10-51\%), exchangeable sodium percentage (ESP) (a rise of 3-46\%), and the decrease in soil
\end{abstract}

S. Rezapour $(\bowtie)$

Soil Science Department, Urmia University, P.O. Box 165, Urmia 57134, Islamic Republic of Iran

e-mail: S.Rezapour@urmia.ac.ir; S_Rezapour2000@yahoo.com organic C (a drop of 12-41\%), along with soil fertility attributes. Overall, the general distribution of soil organic $\mathrm{C}$, total $\mathrm{N}$, available $\mathrm{P}$ and $\mathrm{K}$, cation exchange capacity (CEC), and exchangeable cations $(\mathrm{Ca}, \mathrm{Mg}$, and $\mathrm{K}$ ) followed the order: forestland $>$ grassland $>$ cropland. The general distribution of EC, SAR, ESP, and exchangeable $\mathrm{Na}$, however, followed the order: cropland $>$ grassland $>$ forestland. Soil quality index (SQI), calculated based on some physicochemical properties, specified that cultivation led to a negative effect in SQI for both Cambisols (a drop of 10-17\%) and Vertisols (a drop of $17 \%$ ) as compared to those of under grassland and forestland.

Keywords Land use - Cultivation - Soil attributes . Soil quality $\cdot$ Cambisols $\cdot$ Vertisols

\section{Introduction}

Recent assessment suggests that changes in land use and management can appear as a marked effect in soil attributes as well as soil quality. The changes in soil properties and processes, in turn, can affect pattern of plant growth and environment (Ahuja 2003; Rezapour et al. 2012). Indeed, land use changes and soil management practices influence the soil attributes related soil processes such as oxidation, mineralization, and leaching, etc., and consequently modifying soil quality (Hontoria et al. 1999; Wang et al. 2001). Overall, it is suggested that changes in land use can highlight a crucial threat for the soil system. Soil erosion, soil contamination, decline in organic matter and biodiversity, soil compaction, salinization, floods and landslides, and sealing are the major threats faced by soils (De la Rosa and Sobral 2008; Xiaohong and Zhenghu 2009; Cotching and Kidd 2010) following changes in land use. In this context, the conversion of forests 
and pastures into cropland can have particular impact on soil characteristics (Zucca et al. 2010) due to two factors: (1) the intrinsic factors such as climate, topography, and vegetation, and (2) the extrinsic factors such as fertilization, cultivation, over grazing, and management (Başaran et al. 2008).

Deforestation and destruction of pastures have been noticeably equated with increase in bulk density, organic matter reduction, nutrient depletion, and soil quality degradation (Solomon et al. 2000; Kong et al. 2006; Zhao et al. 2009). Robinson and Philips (2001) remarked that enhanced runoff and loss of soil materials were evident in crop land and livestock-degraded lands, but not in woodlands. Hajabbasi et al. (1997) observed a $20 \%$ increase in bulk density and $50 \%$ decrease in soil organic carbon following deforestation and tillage practices for a soil depth of 0-30 cm over 20 years in the central Iran. Similarly, Gue and Gifford (2002) found that a conversion from either forest to cropland or from grassland to cropland led to 42 and $50 \%$ decrease in soil organic carbon, respectively. Land degradation and loss of organic matter have close relations to soil nutrient depletion as documented by other authors. For example, the data found by Du Toil et al. (1994) in South Africa indicated that 5-90 years land use for cultivation resulted in a loss of 10-73\% of C and $\mathrm{N}$ concentration compared to the native grassland. In USA, when a grassland soil was converted into cultivated land for 60 years, it was highlighted by Bowman et al. (1990) that total organic C, N, and P had decreased by 55-63\%. Zhao et al. (2005) mentioned that total $\mathrm{N}$ and total $\mathrm{P}$ concentrations had declined 60-70 \% and 67-68\% in the 0-20 cm plough layer, respectively, as result of cultivation of grassland.

In recent years, many parts of grassland and forest soils in Iran were converted into agricultural activities. This conversion could contribute to a variety of environmental problems over time such as soil erosion and degradation, desertification, sedimentation, and flooding. In view of the fact that there is a great need to investigate the variability of soil properties as affected by land use changes, an assessment was performed on this aspect in calcareous soils with Mediterranean type climate. The specific objective of this study was (1) to assess the general variability of soil physicochemical and clay mineralogical properties in the three land use types and (2) to evaluate the impact of different land use types on soil quality inferred through monitoring the combination of morphological, clay mineralogical, and physicochemical attributes.

\section{Materials and methods}

\section{Environmental setting}

This work was undertaken at Piranshahr area (36 $30^{\prime}$ to $36^{\circ} 50^{\prime} \mathrm{N}$ latitude and $45^{\circ} 5^{\prime}$ to $45^{\circ} 25^{\prime} \mathrm{E}$ longitude),
Western-Azerbaijan province, north-west of Iran (Fig. 1). The studied region is characterized by a natural beauty agroecosystem including vast and fertile plains, luxuriant forests and pastures. A Mediterranean type of climate exists in Piranshahr area following the variation in climatic parameters such as mean annual precipitation $(650 \mathrm{~mm})$, mean annual temperature $\left(12.5^{\circ} \mathrm{C}\right)$, and mean annual reference crop evapotranspiration $(1,750 \mathrm{~mm})$. This area that is part of Iranian plateau formed in the late period of Quaternary (10000 BP).

The land use types assessed included a cultivated land, a grassland, and a native forestland (as a combination forest trees and pasture plants). Most of the cultivated soils have been cropped under sugar beet-wheat rotations and had received irrigation through rainfall, ground water, or river water in a flooding irrigation system. The detailed results of chemical parameters of irrigation waters used in the cultivated soils are illustrated in Table 1. Based on Salinity Laboratory Staff (1954), quality of irrigation waters employed was in moderate to well category in term of water salinity [electrical conductivity (EC)] and alkalinity (SAR). The native grassland was mainly composed of shrubs and various grass such as: Altheea officinalis, Astragalus's officinalis, Alhagi camelorum, Carthamus oxyacantha, and Achillea milefolium. The major forest cover was Quercus persica followed by Pistacia mutica, Crataegus azarolus, and Acer assyriacum. The land use types were within similar slope, aspect, parent material and the same soil classification. Some of environmental attributes for the investigated land use types were described in Table 2. Composite Surface soils (each composite was include 2-3 single soil sample) from a horizon in relation to three different land use types were described, classified (Soil Survey Staff 2010; FAO/ISRIC/ISSS 2006), and sampled. A total of 42 composite surface soils were analyzed form the three land use types mentioned (14 samples for each land use). Cambisols and Vertisols were the main reference soil groups in the examined land use types. Soil samples taken at each land use were air-dried and sieved (2-mm screen) prior to any analysis. The physicochemical and clay mineralogical analyses were carried out on a less than 2-mm fraction.

\section{Soil physical and chemical analysis}

Content of clay, silt, and sand was measured by pipette following pretreatment with $30 \% \mathrm{H}_{2} \mathrm{O}_{2}$ and hexametaphosphate (Day 1966). Standard methods were used for the determination of soil organic carbon (SOC) (Nelson and Sommers 1982), CCE (Nelson 1982), soil pH (0.01 M $\mathrm{CaCl}_{2}$ suspension), electrical conductivity [(EC), saturation extract], cation exchange capacity (CEC) (Chapman 1965), total N (Nelson and Sommers 1998), and available phosphorus (Olsen and Sommers 1982). Exchangeable and 
Fig. 1 Location map of study region (Scale 1:100000)

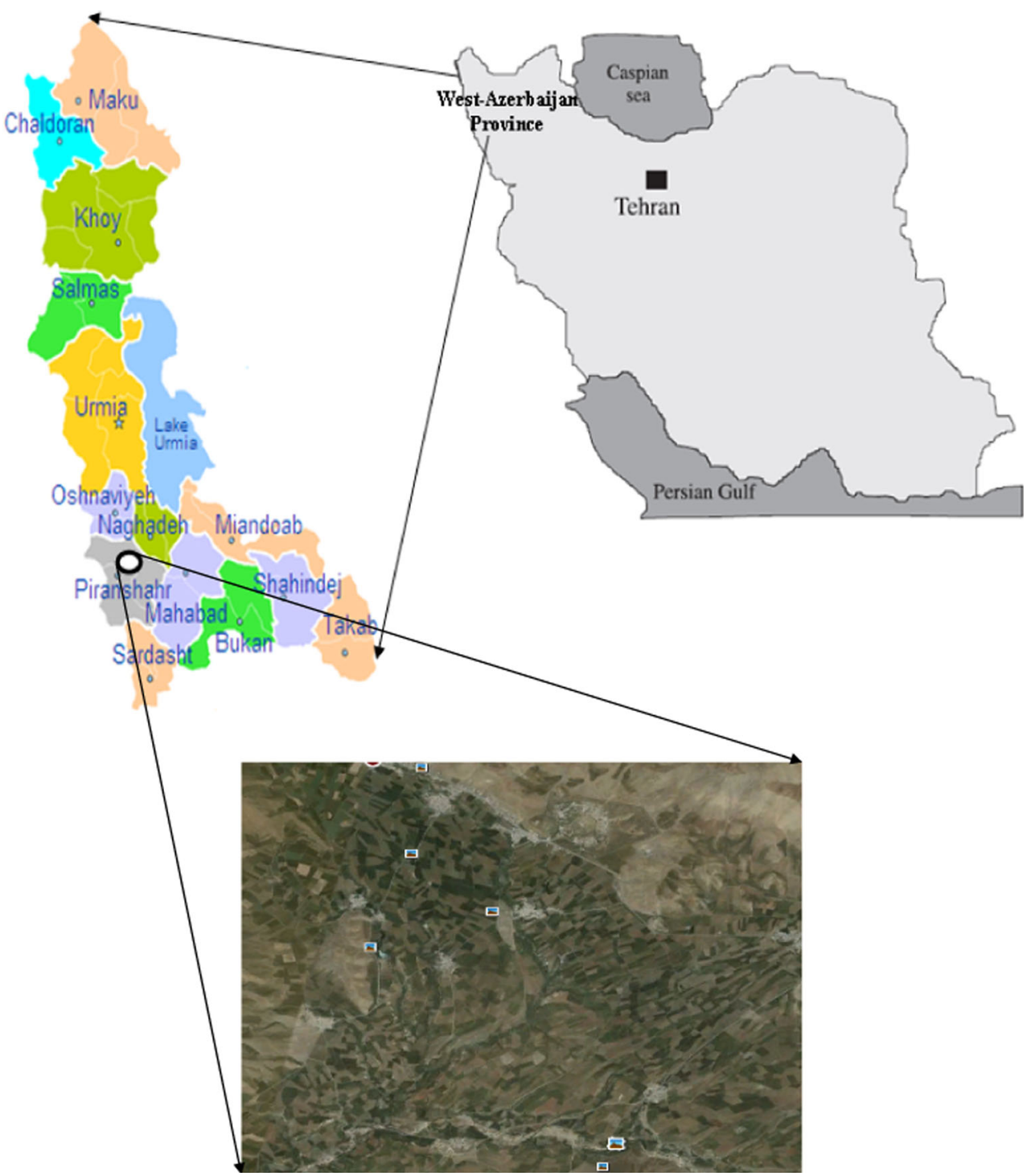

soluble cations ( $\mathrm{Ca}, \mathrm{Mg}, \mathrm{Na}$, and $\mathrm{K}$ ) were extracted by $1 \mathrm{M}$ $\mathrm{NH}_{4} \mathrm{OAc}$ buffered at $\mathrm{pH} 7$ (Thomas 1982) and saturation extract, respectively. The content of $\mathrm{Ca}$ and $\mathrm{Mg}$ along with $\mathrm{Na}$ and $\mathrm{K}$ was determined by an atomic absorption spectrophotometer (Shimadzu AA-6300) and a flame photometer (Corning 400), respectively. SAR was calculated using soil solution $\mathrm{Na}, \mathrm{Ca}, \mathrm{Mg}$ (Salinity Laboratory Staff 1954). ESP was determined through exchangeable $\mathrm{Na}$ and CEC (Salinity Laboratory Staff 1954). The statistical analyses were conducted using SPSS 15 (2006).

Clay minerals analysis

Clay minerals were determined by X-ray diffraction (XRD) technique (Mehra and Jackson 1960; Kunze 1965) following some steps: (1) The removal of soluble salts and carbonates by washing and using $1 \mathrm{~N}$ sodium acetate buffered at $\mathrm{pH} 5$; (2) The removal of organic matter and iron oxides by $30 \% \mathrm{H}_{2} \mathrm{O}_{2}$ and citrate-dithionite-bicarbonate (CDB), respectively; (3) The separation of clay fraction from sand and silt fraction by wet-sieving and centrifugation; (4) The saturation of clay fraction with ions of $\mathrm{Mg}$ and $\mathrm{K}$; (5) The preparation of treatments on glass slides as $\mathrm{Mg}$-saturated, $\mathrm{Mg}$-saturated plus ethylene glycol salvation, $\mathrm{K}$-saturated, and heat of $\mathrm{K}$-saturated at $500{ }^{\circ} \mathrm{C}$; (6) The scan of treatments from $3^{\circ}$ to $30^{\circ} 2 \theta$ with speed of $1^{\circ} 2 \theta$ and a step size of $0.02^{\circ} 2 \theta$ at 1 s/step. A second scan, consist of $24^{\circ}-26^{\circ} 2 \theta$ using a step size of $0.02^{\circ} 2 \theta$ at $5 \mathrm{~s} /$ step with a scan speed of $0.004^{\circ} 2 \theta /$ s, was used to distinguish chlorite from kaolinite (Biscaye 1965; Hein et al. 2003). The second scan was unsuccessful for this purpose so that chlorite and kaolinite were reported together in the study. The percentage of the lay minerals was estimated, semi-quantitatively, based on Biscaye method (1965). 
Table 1 Summary overview of the chemical composition of the irrigation water used for the cultivated soils

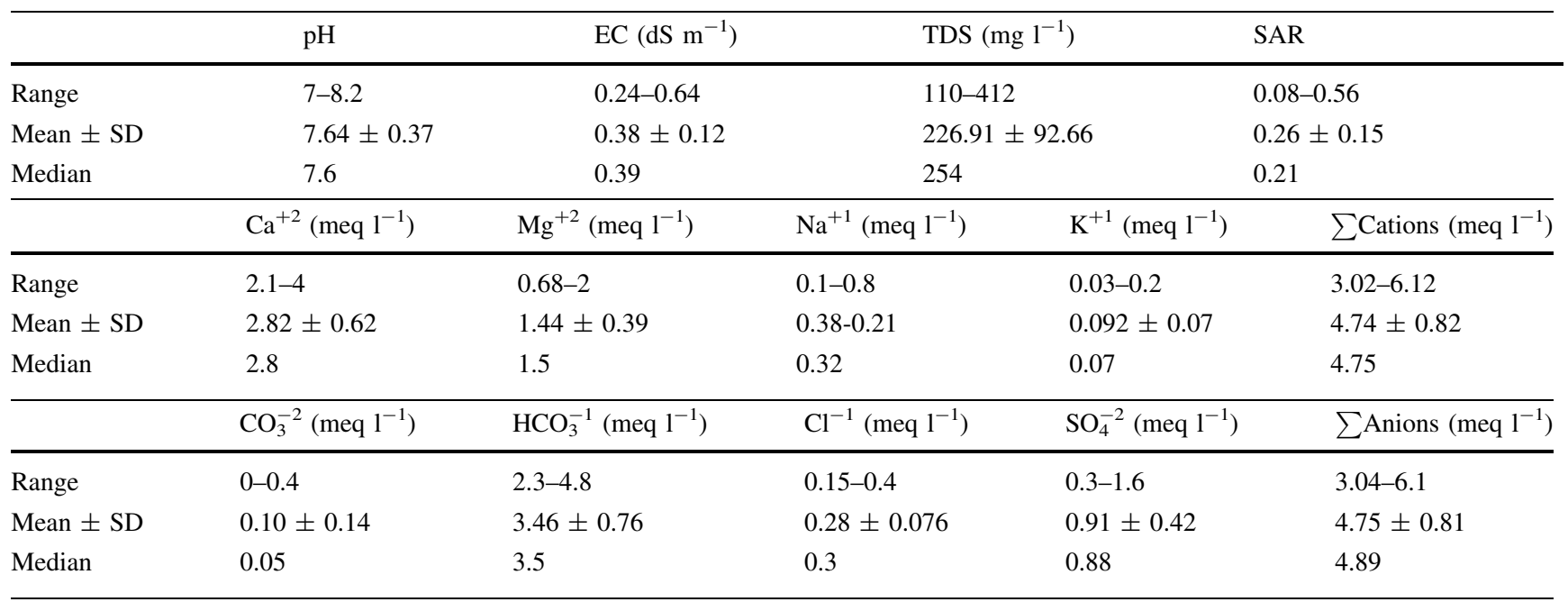

$S D$ standard deviation, $E C$ electrical conductivity, $T D S$ total dissolved solids, SAR sodium adsorption ration

Table 2 General properties for the three land use types studied

\begin{tabular}{llll}
\hline Land use type & Classification & Physiographic position $^{\mathrm{c}}$ \\
\cline { 2 - 3 } & $\mathrm{WRB}^{\mathrm{a}}$ & Soil taxonomy & \\
\hline Cultivated land & Haplic Cambisols (Calcaric) & Typic Haploxerepts & Piedmont alluvial plain \\
& Calcic Vertisols (Eutric) & Typic Calcixererts & Piedmont alluvial plain \\
Grassland & Haplic Cambisols (Calcaric) & Typic Haploxerepts & Piedmont alluvial plain (upper part) \\
& Calcic Vertisols (Eutric) & Typic Calcixererts & Piedmont alluvial plain (upper part) \\
Forest land & Haplic Cambisols (Calcaric) & Typic Haploxerepts & Piedmont alluvial plain (upper part) \\
& Calcic Vertisols (Eutric) & Typic Calcixererts & Piedmont alluvial plain (upper part)
\end{tabular}

\footnotetext{
${ }^{a}$ World Reference Base for Soil Resources (FAO/ISRIC/ISSS 2006)

b Soil Survey Staff (2010)

${ }^{c}$ Drainage condition and parent material were as well-drained and Cretaceous formation, respectively, for all the studied
}

\section{Results and discussion}

\section{Morphophysical characteristics}

There was marked differences on the morphological behavior of soils among the three land use types in both Cambisols and Vertisols (Table 3). In this context, weakening in soils structure, hardening of consistency, and lightning of color occurred for cropland under comparable conditions with grassland and forest. In general, strong to medium granular structure of grassland and forest was replaced by fine angular blocky structure in cropland soils as result of traffic activities or mechanical stresses. Soil color was modified from reddish brown (10YR4/3) and dark brown (10YR3/3) in grassland and forest to yellowish brown (10YR5/4 and 10YR5/6) in cropland. Indeed, cultivation led to the lightning of soil color through increase in soil value (as an indicator of lightness or darkness) mainly due to destruction of the organic residues. The change in land use also exerted a major influence on soil consistency. Consistency degree of friable to very friable in grassland and forest was replaced by firm to very firm in the tilled soils (Table 3).

Particle-size distribution among land use types indicated some changes in both the studied soil types (Table 3). However, there was no statistically significant difference in percent distribution of sand, silt, and clay among the three land use types. The cultivated soils were noticeably lower in silt and clay contents and higher in sand fraction compared to those of the adjoining grassland and forestland. By the mean, silt and clay contents were in the order of forestland $>$ grassland $>$ cropland whereas sand content was in the order of cropland $>$ grassland $>$ forestland (Table 3). Through cultivation, sand content was increased by $4-35 \%$ while silt and clay contents were decreased by 2-22\% and 2-18\%, respectively, compared to those of 
Table 3 Selected morphophysical properties for the three land use types studied

\begin{tabular}{|c|c|c|c|c|c|c|}
\hline \multirow[t]{2}{*}{ Variable } & \multicolumn{3}{|l|}{ Cambisols } & \multicolumn{3}{|l|}{ Vertisols } \\
\hline & Cultivated soil & Grassland & Forest land & Cultivated soil & Grassland & Forest land \\
\hline Structure $^{\mathrm{a}}$ & f2abk & $\mathrm{m} 1 \mathrm{gr}$ & $\mathrm{m} 1 \mathrm{gr}$ & f2abk & $\mathrm{m} 2 \mathrm{gr}$ & $\mathrm{m} 3 \mathrm{gr}$ \\
\hline Color (moist) & 10YR 5/6 & $10 \mathrm{YR} 4 / 3$ & $10 \mathrm{YR} 4 / 3$ & 10YR 5/4 & $10 \mathrm{YR} 4 / 3$ & $10 Y R 3 / 3$ \\
\hline Consistence $^{\mathrm{b}}$ (moist) & vfi & fri & fri & fi & fri & vfri \\
\hline Sand $(\%)^{\mathrm{c}}$ & $38.2 \pm 14.99^{\mathrm{a}}$ & $34.52 \pm 18.2^{\mathrm{a}}$ & $29.52 \pm 12.81^{\mathrm{a}}$ & $27.4 \pm 16.72^{\mathrm{a}}$ & $24.86 \pm 14.19^{\mathrm{a}}$ & $21.0 \pm 12.42^{\mathrm{a}}$ \\
\hline Silt $(\%)$ & $31.0 \pm 9.16^{\mathrm{a}}$ & $33.97 \pm 8.89^{\mathrm{a}}$ & $36.5 \pm 8.94^{\mathrm{a}}$ & $33.46 \pm 6.7^{\mathrm{a}}$ & $34.42 \pm 10.56^{\mathrm{a}}$ & $35.6 \pm 6.11^{\mathrm{a}}$ \\
\hline Clay $(\%)$ & $30.8 \pm 7.79^{\mathrm{a}}$ & $31.53 \pm 10.52^{\mathrm{a}}$ & $33.97 \pm 9.72^{\mathrm{a}}$ & $39.14 \pm 11.33^{\mathrm{a}}$ & $40.72 \pm 10.55^{\mathrm{a}}$ & $43.4 \pm 9.86^{\mathrm{a}}$ \\
\hline Texture & Clay loam & Clay loam & Clay loam & Clay & Clay & Clay \\
\hline
\end{tabular}

${ }^{a}$ Grade: 1 weak, 2 moderate, 3 strong. Size: $f$ fine, $m$ medium. Type: $g r$ granular, $a b k$ angular blocky

${ }^{\mathrm{b}} f i$ firm, $v f i$ very firm, fri friable, $v f r i$ very friable

c Means followed by the same latter in row for each fraction are not significantly different

the adjoining grassland and forest. Presence of greater silt and clay contents in soils from the grassland and forestland could be attributed to: (1) accelerated alteration induced by natural and suitable conditions in the grassland and forest ecosystems; for instance, increasing of weathering processes in the grassland and forest could be highlighted through increasing of the secondary clay silicates (smectite) compared with the cropland (as will be discussed later). Indeed, accelerated weathering of primary minerals like micaceous minerals probably led to increased production of layer silicate clays in the grassland and forest; (2) well-covered vegetation in the grassland and mainly forest protects the soil against erosion (Abbasi et al. 2007). The grassland and forest have a long-growth period and high vegetation and biomass, therefore, land surface was well-covered and directly protected from strong erosion. On the contrary, the cultivated soils had a short-growth period along with low biomass and land surface was left bare after harvest (Zhao et al. 2005), resulted in accelerating soil erosion and losing clay and silt fractions. As a consequence, it can be said that the grassland and mainly forest through the tree canopy, surface litter, biomass, and root may have stabilized and protected these soils from significant surface erosion (Stolt et al. 1993). This pattern can provide favorable conditions for activation of soil forming processes mainly weathering and synthesis of clay fraction.

\section{Clay mineralogy characteristics}

XRD analyses of clay fraction suggest that the examined soils are predominantly composed of illite, smectite, chlorite, and kaolinite. The semi-quantitative estimate of clay minerals is exhibited in Table 4 and the pertaining $\mathrm{X}$-ray patterns are presented in Fig. 2. Changes in land use types and soil type did not cause noticeable modification in the XRD pattern of chlorite and kaolinite regarding the quantity and the intensity or in the position of peaks of them. This trend is not surprising, especially, in view of the fact that chlorite and kaolinite are very stable against weathering process in calcareous and alkaline soil like the region investigated (Khormali and Abtahi 2003; Rezapour et al. 2009). Variability of illite and smectite was strongly evident following changes in land use and soil type. Variation of illite was in the rank of cultivated soil $>$ grassland $>$ forestland, whereas smectite was in the order of forestland $>$ grassland $>$ cultivated soil. Indeed, two opposite patterns in illite and smectite distribution were highlighted in the forestland. This pattern suggested that these two clay minerals are largely related together through genetic pathways following water-plant activity-soil processes interaction in the forest land ecosystem. In this context, smectitization process as result of expanse of illite layer (peak of $10 \AA$ ) to smectite (peak of 17-18 $\mathrm{A}$ ) through a disordered stacking sequence (interstratified illite/
Table 4 Semi-quantitative percentage of clay minerals for the three land use types studied

\begin{tabular}{|c|c|c|c|c|c|c|}
\hline \multirow[t]{2}{*}{ Clay mineral } & \multicolumn{3}{|l|}{ Cambisols } & \multicolumn{3}{|l|}{ Vertisols } \\
\hline & $\begin{array}{l}\text { Cultivated } \\
\text { soil }\end{array}$ & Grassland & $\begin{array}{l}\text { Forest } \\
\text { land }\end{array}$ & $\begin{array}{l}\text { Cultivated } \\
\text { soil }\end{array}$ & Grassland & $\begin{array}{l}\text { Forest } \\
\text { land }\end{array}$ \\
\hline Illite & 32 & 29 & 20 & 30 & 28 & 18 \\
\hline Smectite + mixed layered minerals & 18 & 23 & 35 & 22 & 25 & 40 \\
\hline Chlorite + Kaolinite & 49 & 48 & 45 & 48 & 47 & 42 \\
\hline
\end{tabular}



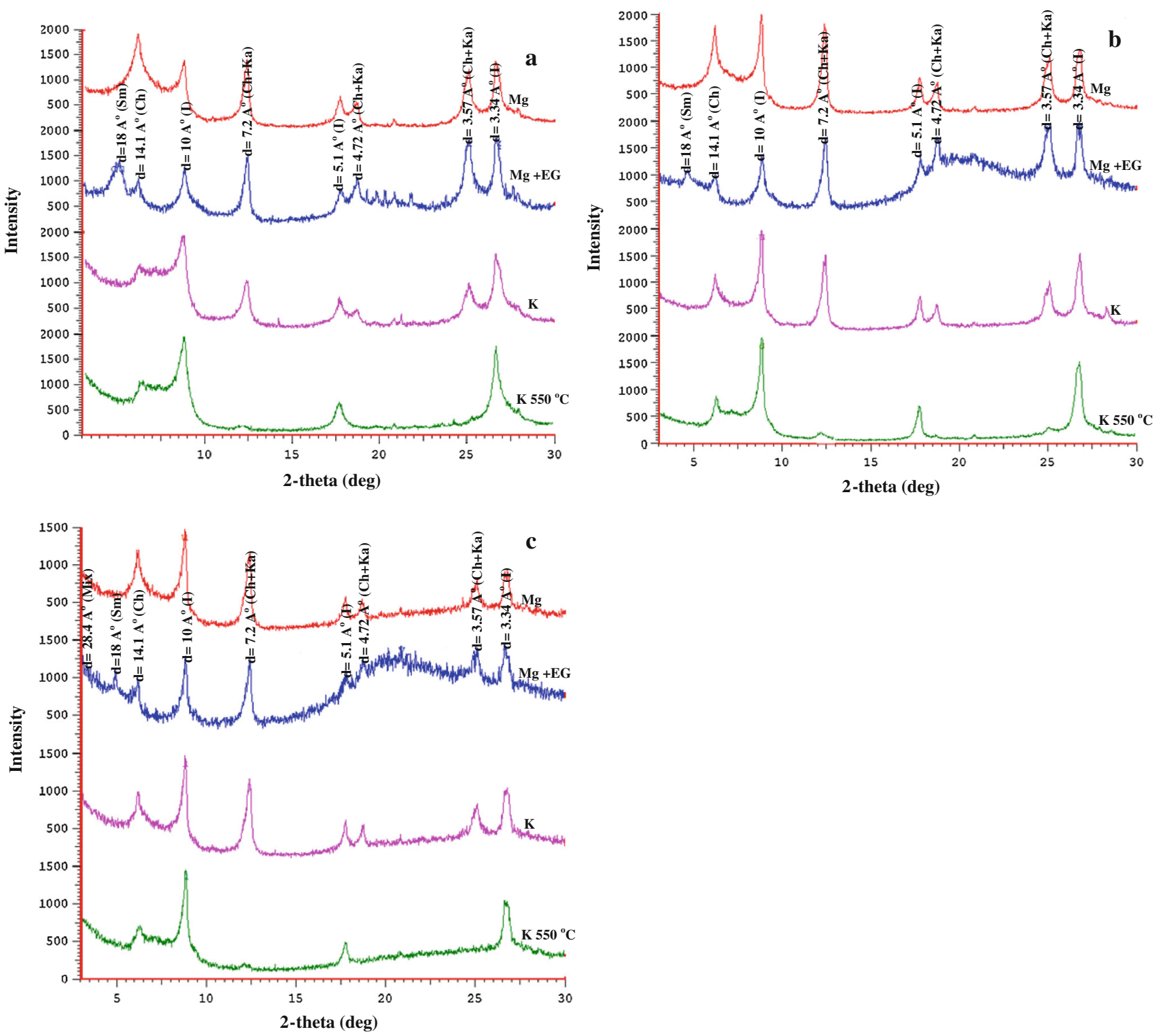

Fig. 2 The XRD patterns for the clay fractions from the Vertisols area in forestland (a), grassland (b), and cropland (c). Sm smectite, $C h$ chlorite, $I$ illite, $K a$ kaolinite

smectite phase) in a $\mathrm{K}$ removal environment can be an acceptable reason for trends of illite and smectite. This assessment is in agreement to other researcher (Barre et al. 2007, 2009). As emphasized, it can be said that the natural forest promoted remarkably the expansion of illite layers (peak of $10 \AA$ ) toward smectite (peak of $18 \AA$ ) compared to other land use (cultivated soil and grassland) based on $\mathrm{X}$-ray patterns. On the other hand, increasing pattern of smectite in the forestland was in parallel with an decreasing and increasing pattern, respectively, for clay and sand (as discussed before) indicating that smectite may be associated with weathering of primary minerals such as feldspars (Dixon and Schulz 2002). In addition, inherent origin (from bedrock) along with transformation of primary $\mathrm{K}$ bearing (such as mica feldspars) was considered as the main pathway for occurrence of illite (Rezapour et al. 2009).

Soil chemical and fertilitical characteristics

Mean $( \pm \mathrm{SD})$ values of selected soil chemical and fertilitical attributes are presented in Table 5. The mean soil $\mathrm{pH}$ of the three land use types showed that soil from the forestland had the minimum $\mathrm{pH}$ followed by the cropland and grassland in both Cambisols and Vertisols. While the variability of $\mathrm{pH}$ (mean) appears to be uniform in the cultivated soil and grassland, continuous cultivation led to a rise of 0.30 unit in soil $\mathrm{pH}$ for Cambisols and 0.46 unit for Vertisols compared to the adjacent soils under forest. This 
Table 5 Mean \pm standard deviation values of chemical and fertilitical properties for the three land use types studied

\begin{tabular}{|c|c|c|c|c|c|c|}
\hline \multirow[t]{2}{*}{ Variable } & \multicolumn{3}{|l|}{ Cambisols } & \multicolumn{3}{|l|}{ Vertisols } \\
\hline & Cultivated soil & Grassland & Forest land & Cultivated soil & Grassland & Forest land \\
\hline $\mathrm{pH}$ & $7.4 \pm 0.29^{\mathrm{a}}$ & $7.4 \pm 0.28^{\mathrm{a}}$ & $7.1 \pm 0.28^{\mathrm{a}}$ & $7.54 \pm 0.05^{\mathrm{b}}$ & $7.48 \pm 0.03^{\mathrm{b}}$ & $7.08 \pm 0.23^{\mathrm{a}}$ \\
\hline $\mathrm{EC}\left(\mathrm{dS} \mathrm{m} \mathrm{m}^{-1}\right)$ & $0.775 \pm 0.18^{\mathrm{b}}$ & $0.435 \pm 0.10^{\mathrm{a}}$ & $0.385 \pm 0.11^{\mathrm{a}}$ & $1.51 \pm 0.62^{\mathrm{b}}$ & $0.342 \pm 0.05^{\mathrm{a}}$ & $0.272 \pm 0.09^{\mathrm{a}}$ \\
\hline SAR $\left(\mathrm{mmol} \mathrm{L}^{-1}\right)$ & $2.92 \pm 0.36^{\mathrm{a}}$ & $2.73 \pm 0.53^{\mathrm{a}}$ & $2.63 \pm 0.06^{\mathrm{a}}$ & $3.33 \pm 1.10^{\mathrm{b}}$ & $2.30 \pm 0.48^{\mathrm{a}}$ & $2.2 \pm 0.20^{\mathrm{a}}$ \\
\hline $\operatorname{CCE}\left(\mathrm{g} \mathrm{kg}^{-1}\right)$ & $43.33 \pm 26.22^{\mathrm{b}}$ & $42.20 \pm 36.5^{\mathrm{b}}$ & $35.02 \pm 22.81^{\mathrm{a}}$ & $96.80 \pm 104.13^{\mathrm{b}}$ & $96.66 \pm 99.67^{\mathrm{b}}$ & $63.90 \pm 72.67^{\mathrm{a}}$ \\
\hline $\mathrm{OC}\left(\mathrm{g} \mathrm{kg}^{-1}\right)$ & $7.33 \pm 3.44^{\mathrm{a}}$ & $10.33 \pm 6.31^{\mathrm{a}}$ & $27.8 \pm 4.03^{\mathrm{b}}$ & $11.40 \pm 1.52^{\mathrm{a}}$ & $12.80 \pm 2.28^{\mathrm{a}}$ & $27.60 \pm 2.97^{\mathrm{b}}$ \\
\hline Total $\mathrm{N}\left(\mathrm{g} \mathrm{kg}^{-1}\right)$ & $1.1 \pm 0.17^{\mathrm{a}}$ & $1.04 \pm 0.26^{\mathrm{a}}$ & $2.8 \pm 0.20^{\mathrm{b}}$ & $1.13 \pm 0.01^{\mathrm{a}}$ & $1.3 \pm 0.24^{\mathrm{a}}$ & $2.43 \pm 0.59^{\mathrm{b}}$ \\
\hline Available P $\left(\mathrm{mg} \mathrm{kg}^{-1}\right)$ & $24 \pm 3.61^{\mathrm{b}}$ & $10.0 \pm 2.65^{\mathrm{a}}$ & $39.67 \pm 2.08^{c}$ & $11.0 \pm 1.0^{\mathrm{a}}$ & $13.0 \pm 1.0^{\mathrm{a}}$ & $29.33 \pm 2.08^{\mathrm{b}}$ \\
\hline Available $\mathrm{K}\left(\mathrm{mg} \mathrm{kg}^{-1}\right)$ & $345.0 \pm 5.0^{\mathrm{a}}$ & $450.0 \pm 10.0^{\mathrm{b}}$ & $482.0 \pm 18.93^{\mathrm{c}}$ & $340.0 \pm 10.0^{\mathrm{a}}$ & $410.0 \pm 26.46^{\mathrm{b}}$ & $426.67 \pm 5.77^{\mathrm{b}}$ \\
\hline $\mathrm{Ca}\left(\mathrm{cmol}_{\mathrm{c}} \mathrm{kg}^{-1}\right)$ & $19.0 \pm 1.0^{\mathrm{a}}$ & $19.5 \pm 0.5^{\mathrm{ab}}$ & $20.67 \pm 0.58^{\mathrm{ab}}$ & $22.0 \pm 2.0^{\mathrm{a}}$ & $22.33 \pm 0.58^{\mathrm{a}}$ & $23.0 \pm 1.0^{\mathrm{a}}$ \\
\hline $\operatorname{Mg}\left(\mathrm{cmol}_{\mathrm{c}} \mathrm{kg}^{-1}\right)$ & $6.2 \pm 0.10^{\mathrm{a}}$ & $6.1 \pm 0.15^{\mathrm{a}}$ & $6.4 \pm 0.10^{\mathrm{ab}}$ & $6.73 \pm 0.21^{\mathrm{a}}$ & $7.7 \pm 0.26^{\mathrm{b}}$ & $7.77 \pm 0.25^{\mathrm{b}}$ \\
\hline Exchangeable $\mathrm{K}\left(\mathrm{cmol}_{\mathrm{c}} \mathrm{kg}^{-1}\right)$ & $0.75 \pm 0.03^{\mathrm{a}}$ & $0.87 \pm 0.01^{\mathrm{b}}$ & $0.88 \pm 0.02^{\mathrm{b}}$ & $0.83 \pm 0.05^{\mathrm{a}}$ & $1.07 \pm 0.07^{\mathrm{ab}}$ & $1.18 \pm 0.03^{\mathrm{b}}$ \\
\hline $\mathrm{Na}\left(\mathrm{cmol}_{\mathrm{c}} \mathrm{kg}^{-1}\right)$ & $0.91 \pm 0.58^{\mathrm{a}}$ & $0.90 \pm 0.53^{\mathrm{a}}$ & $0.88 \pm 0.02^{\mathrm{a}}$ & $1.47 \pm 0.03^{\mathrm{b}}$ & $1.13 \pm 1.10^{\mathrm{a}}$ & $1.07 \pm 0.06^{\mathrm{a}}$ \\
\hline $\operatorname{ESP}(\%)$ & $3.52 \pm 0.52^{\mathrm{a}}$ & $3.43 \pm 0.59^{\mathrm{a}}$ & $3.0 \pm 0.2^{\mathrm{a}}$ & $4.40 \pm 1.05^{\mathrm{b}}$ & $3.06 \pm 0.13^{\mathrm{a}}$ & $3.0 \pm 0.2^{\mathrm{a}}$ \\
\hline $\mathrm{CEC}\left(\mathrm{cmol}_{\mathrm{c}} \mathrm{kg}^{-1}\right)$ & $26.83 \pm 5.15^{\mathrm{a}}$ & $27.5 \pm 7.56^{\mathrm{a}}$ & $29.80 \pm 4.55^{\mathrm{a}}$ & $31.40 \pm 8.56^{\mathrm{a}}$ & $32.40 \pm 7.13^{\mathrm{a}}$ & $35.20 \pm 6.61^{\mathrm{ab}}$ \\
\hline
\end{tabular}

$C C E$ calcium carbonate equivalent, $O M$ organic matter, $S A R$ sodium adsorption ratio, ESP, exchangeable sodium percentage

a, b, c, ab Values are non significant $(P<0.05)$

pattern may be explained by tillage practices such as (1) the mixing of surface soil with subsurface soil containing carbonates (Kettler et al. 2000) and (2) the irrigation practices containing a noticeable content salts and bicarbonate as showed by the used irrigation water (Table 1). Although the determined $\mathrm{pH}$ values were in an optimal range (6-7.5) for all the studied soils, it was found that cultivation had a negative effect on soil quality because of any increase in soil $\mathrm{pH}$ can be considered as a negative aspect in the alkaline and calcareous soils (Smith and Doran 1996). In contrast, the grassland and forest had no change and positive changes on soil quality, respectively, than the soils under cultivation with respect to soil $\mathrm{pH}$.

Long-term cultivation significantly changed the EC and SAR of the soils compared to the adjacent soils under grass land and forest (Table 5). On an average, the soil from cropland had 1.78 (Cambisols) to 4.38 (Vertisols) and 2.0 (Cambisols) to 5.5 (Vertisols) times higher EC than soils from grassland and forest, respectively. Similarly, SAR contents of the cropland were $10 \%$ (Cambisols) to $45 \%$ (Vertisols) and $12 \%$ (Cambisols) to $51 \%$ (Vertisols) greater than those of the grassland and forest, respectively, indicating that the general distribution SAR was matching with distribution pattern of EC. In view of the fact that the applied irrigation water had a remarkable concentration of salts as displayed by its EC and TDS (Table 1), increasing pattern of EC and SAR was not surprising in the cultivated soils. In spite of soil quality being affected negatively by increasing soil salinity in the cultivated soils, the EC values were in the acceptable range $\left(0-1.5 \mathrm{dS} \mathrm{m}^{-1}\right)$ for "general plant growth and microbial activity" (Smith and Doran 1996).

Calcium carbonate equivalent values under forest declined significantly $(P \leq 0.05)$ compared to those of the adjoining grassland and cropland in both Cambisols and Vertisols (Table 5). The mean CCE of the soils from grassland and cropland was almost similar (i.e. 96.7 and $96.8 \mathrm{~g} \mathrm{~kg}^{-1}$ in the Cambisols), whereas the mean CCE value in the forest was 20-23\% (Cambisols) and $51.3-51.5 \%$ (Vertisols) lower than those of grassland and cropland. This pattern can be attributed to high tend of forest land for the dissolution/translocation of calcium carbonates. In the light of this, lithogenic carbonates were dissolved under ambient moisture and level high soil $\mathrm{CO}_{2}$ partial pressure leading to CCE leaching from soil surface to greater depth with the percolating soil water in the natural forest (Wang and Anderson 1998; Rubio and Escudero 2005). Contrary to forest land, calcareous parent material is tilled in the cultivated soils by farmers to retain a certain depth of cultivated soil leading to increased $\mathrm{CaCO}_{3}$ in the cropland ( $\mathrm{Ni}$ and Zhang 2007).

Similarly, general distribution SOC and total $\mathrm{N}$ were in the order of forestland $>$ grassland $>$ cropland for both Cambisols and Vertisols. Impact of different land use types on OC indicated that soils from the cropland had $12 \%$ (Vertisols) to $41 \%$ (Cambisols) and $15 \%$ (Vertisols) to $18 \%$ (Cambisols) low OC and total N, respectively, than the adjacent soils under the grassland (Table 5). These differences were so wider as compared to the cropland and forestland. Significantly, OC content and total N (mean) of 
cropland were 2.4 (Vertisols) to 3.8 (Cambisols) and 1.82 (Vertisols) to 2.5 (Cambisols) times, respectively, lower than that of forest soil (Table 5), showing that degrading effects of cultivation on soil quality are into a crucial category. These findings are comparable to the observation by Hajabbasi et al. (1997) who found that forestland had approximately three times more $\mathrm{OC}$ and total $\mathrm{N}$ than those of under the cultivation. Overall, the combination of fewer plant residues return and biomass after harvest, continuous cropping and frequent burning, faster decomposition rates of organic matter, and greater erosion can be subjected to declining SOC and total $\mathrm{N}$ and destroying soil quality in the studied region following long-term cultivation. Under the cultivation environment, much of the plant material is removed for human and animal food and relatively less remains its way back to the soil, making soil more susceptible to water erosion and runoff. On the other hand, tillage operations aerated the soil and broke up the organic residues, providing them more accessible to decomposition (Brady and Weil 1999). The organic matter content of the Vertisols was generally much higher than those of the Cambisols in the three land use types. This trend may be explained by the higher clay percentage in soils containing Vertisols, making clay-humus complexes that protect the
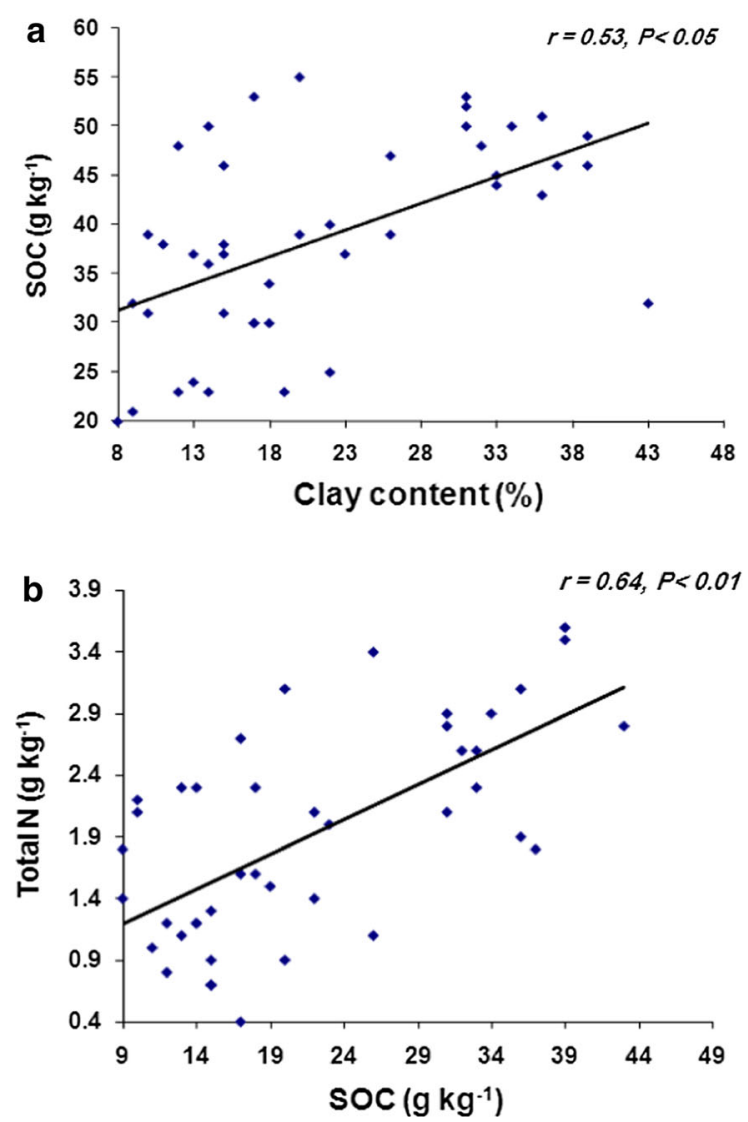

organic matter from oxidation and degradation (Quiroga et al. 1996; Brady and Weil 1999). This assessment was more evident through occurrence of a recorded close correlation between SOC and clay content (Fig. 3a). In fact, the general distribution SOC was matching with distributive pattern of clay fraction. Soil organic carbon positively and significantly correlated with total $\mathrm{N}$ (Fig. 3b) indicating that total $\mathrm{N}$ is particularly released from SOC mineralization. In summary, loss of soil organic matter and total $\mathrm{N}$ under cultivation system are some factors in the examined region involving burning or removal of residues after harvest, clay content, soil types, and erosion.

Soil under continuous cultivation had both negative and positive effects on available phosphorous content as compared to forestland and grassland (Table 5). The mean soil $\mathrm{P}$ contents were found in the order of forestland $>$ cropland $>$ grassland for both Cambisols and Vertisols. On average, $\mathrm{P}$ content of cropland was 2.4 times higher and 1.65 time lower compared to those of the adjoining grassland and forestland, respectively, in the Cambisols. For the Vertisols, cultivation led to phosphorous pattern as 1.2 times higher and 2.3 times lower than the adjacent soil under grassland and forest, respectively. These results are in line with other authors (Bowman et al. 1990; Hajabbasi
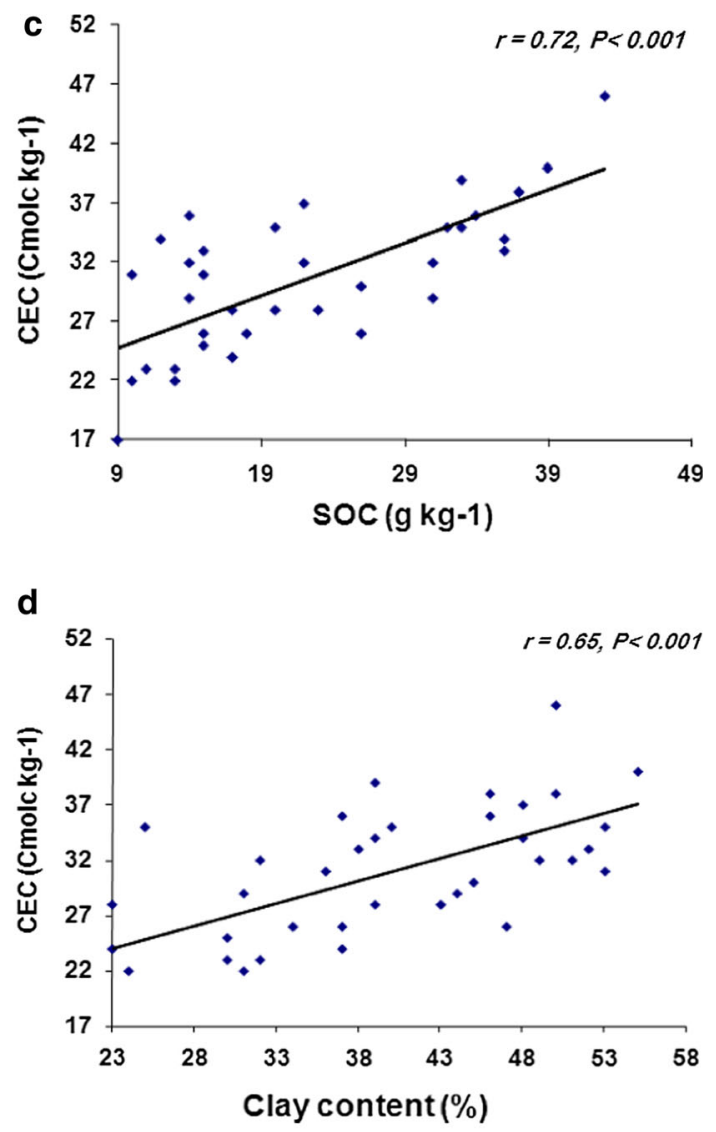

Fig. 3 Correlation coefficient of SOC with clay content (a), total N (b), CEC (c), and CEC with clay content (d) 
et al. 1997; Liu et al. 2002). Significant increase of $P$ content $(P \leq 0.05)$ in the forestland (Table 5) may be associated with relative high SOC and low erosion in the land use type. High level of $\mathrm{OC}$ in the forestland can release soluble phosphorous compounds when organic residues and humus decompose as proposed by other works (Kamprath 1999; Yu et al. 2005). Organic matter can also improve available $\mathrm{P}$ by blocking or masking the phosphorus fixation site. By contrast, the combination of tillage activities along with very low SOC input during harvest that leaves the soil bare and unprotected from the ravages of erosion (Brady and Weil 1999) can contribute to the significant differences between cultivated soils and natural ecosystems like forest regarding to available P.

Long-term cultivation specified a significant decline $(P \leq 0.05)$ in available $\mathrm{K}$ compared to those of the adjoining grassland and forestland (Table 5) and the order was forestland $>$ grassland $>$ cropland for both Cambisols and Vertisols. Through the mean, soils under cultivation manifested a drop of $30 \%$ (Cambisols) to $21 \%$ (Vertisols) and $40 \%$ (Cambisols) to $26 \%$ (Vertisols) than the adjacent soil under grassland and forest, respectively. This means that depletion of available $\mathrm{K}$ was low in the Vertisols area than the soils under Cambisols area, mainly due to variation in clay content, nature and types of clay minerals, CEC, and organic matter. It seems that the greater clay content, nature and smectite content, and corresponding large surface area and CEC manifested higher available $\mathrm{K}$ in the Vertisols (Srinivasarao et al. 2007). Accumulation of significant more available $\mathrm{K}$ in the forestland may be explained by a process involving the biocycling of K. Trees in the forest region scavenge $\mathrm{K}$ from deeper within the soil, incorporate it into their biomass and return it to the soil surface in litter, making an enrichment aspect of $\mathrm{K}$ following litter decomposition (Graham and O'Geen 2010).

Intensive cropping specified a depletion face in exchangeable $\mathrm{Ca}, \mathrm{Mg}$ and $\mathrm{K}$ compared to those of the adjoining grassland and forestland and the order was forestland $>$ grassland $>$ cropland for both Cambisols and Vertisols (Table 5). Accumulation of more exchangeable cations $(\mathrm{Ca}, \mathrm{Mg}$ and $\mathrm{K}$ ) in the forest can be associated with a process known as the "nutrient pumps or nutrient uplift". In the forest land, deep-rooted trees often act as nutrient pumps, taking exchangeable cations form deep subsoil horizons into their root systems, translocating it to their leaves, and re-entering it to the soil surface with litter fall and decomposition, causing much higher exchangeable cations levels in the natural forests.

Soils under long-term cultivation reflected a negligible increase and significant increase in exchangeable $\mathrm{Na}$ in the Cambisols and Vertisols, respectively, than the adjacent soils under grassland and forest (Table 5). A similar pattern was observed for ESP, suggesting that the overall distribution of ESP was matching with exchangeable-Na pattern. Increase of sodium on the exchange complex in the cultivation system can be explained by the quality of the irrigation water. The irrigation water samples for the cultivated soil had a remarkable bicarbonate content (Table 1) that can reduce concentration of $\mathrm{Ca}^{+2}$ and $\mathrm{Mg}^{+2}$ in the soil solution by precipitating these ions as insoluble carbonates such as $\mathrm{CaCO}_{3}$ and $\mathrm{Ca} \mathrm{Mg}\left(\mathrm{CO}_{3}\right)_{2}$, making an increasing aspect in exchangeable $\mathrm{Na}$ through time. Such process, finally, causes an increasing pattern in soil ESP as documented by Corwing et al. (2003) and Pal et al. (2003).

Long-term cropping induced a decrease, although not significant, in CEC compared to those of the grassland and forestland in both Cambisols and Vertisols, probably as a result of destruction in SOC and variation in clay minerals (illite and smectite). In the light of this pattern, cultivation was associated with a drop of $5 \%$ (Cambisols) to $10 \%$ (Vertisols) and $12 \%$ (Cambisols) to $20 \%$ (Vertisols) in mean of CEC than soils from grassland and forest, respectively. Such pattern of CEC was matching with distributive pattern of SOC and clay content, showing that $\mathrm{CEC}$ is a function of organic matter and clay fraction (Rezapour and Samadi 2012). This assessment is more evident through appearance of a significant correlation between CEC and SOC (Fig. 3c) and CEC and clay content (Fig. 3d).

\section{Soil quality index (SQI)}

Soil scientists have developed the concept of soil quality to help quantify factors that are influencing the ability of the soil to function effectively in a variety of roles (Brady and Weil 1999). In order to better illustrate the impact of different land use types on soil attributes, a soil quality index (SQI) was examined using development programs of USDA to evaluate the influence of environmental and managerial stressors on soil health (Amacher et al. 2007). This index integrating numerous soil physicochemical attributes into a single number can be applied to monitor modifications in soil properties by time. The considered SQI had a significant correlation with soil properties, e.g. with SOC $(r=0.75, P \leq 0.001)$, with total $\mathrm{N}(r=0.74$, $P \leq 0.001)$, with Ex-K $(r=0.70, P \leq 0.001)$, and with SAR $(r=-0.58, P \leq 0.001)$ as reported by Rezapour and Samadi (2012). Nine major soil physicochemical properties including coarse fragments, soil $\mathrm{pH}, \mathrm{SOC}$, total $\mathrm{N}$, exchangeable cations $\mathrm{K}, \mathrm{Ca}$ and $\mathrm{Mg}$, ESP, and Olsen-P were used for calculating the mentioned SQI. The individual index values for all the mentioned properties are summed to give a total SQI (for details, see Amacher et al. 2007) as: 
Total SQI $=\sum$ individual soil properties index values.

The total SQI of cropland, grassland, and forest were 10, 11, and 12 for the Cambisols area and 11, 11, and 12 for the Vertisols area, respectively.

The total SQI is then expressed as a percentage of the maximum possible value of the total SQI for the soil properties that are measured as follow:

$$
\begin{aligned}
\mathrm{SQI} \%= & (\text { total SQI } / \text { maximum possible total SQI for } \\
& \text { properties measured }) \times 100
\end{aligned}
$$

The results showed that cultivation led to a negative effect on SQI (a drop of 10-17\%) compared to those of the adjoining grassland and forestland mainly in the Cambisols area. On average, the SQI values of the soils from cropland, grassland, and forest in the Cambisols area were 66.7, 73.3, and $80 \%$, respectively. This pattern indicates that soil from the cropland had 9 and $17 \%$ lower SQI value than the adjacent soils under grassland and forest, respectively, in the Cambisols (Fig. 3a). In the Vertisols area, cropland produced (1) no effect on SQI compared to grassland and (2) $17 \%$ drop in SQI than the adjacent soils under forest (Fig. 3b). Changes in soil organic matter and $\mathrm{pH}$ were the major factors affecting the SQI yield. However, we suggest
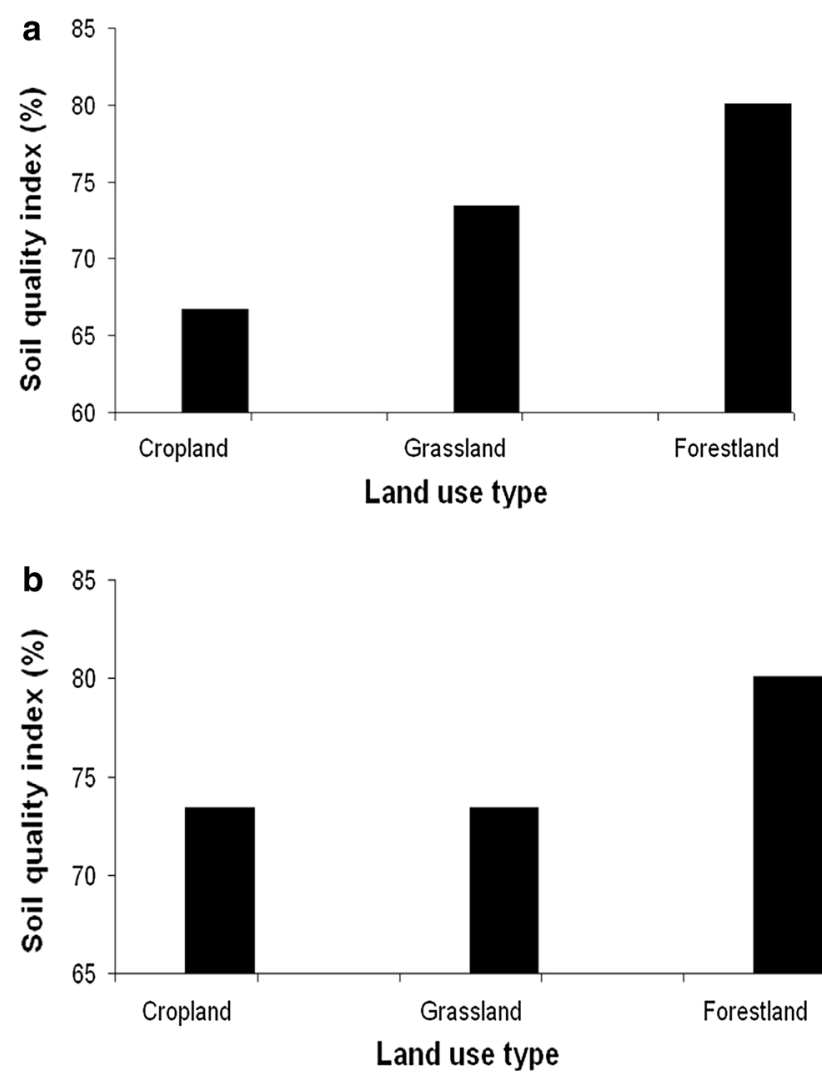

Fig. 4 Variations of soil quality index for the Cambisols area (a) and Vertisols area (b) that EC can be also important in SQI values. As mentioned before, a significant rise in soil EC occurred through cultivation in both Cambisols and Vertisols but it was not considered in this SQI. Therefore, it seems that the examined SQI need to be refined mainly in calcareous soils where dynamic soluble salts are significant following agricultural practices (Fig. 4).

\section{Conclusion}

It can be concluded that land use changes exerted a remarkable influence on the combination of morphological, clay mineralogical and physicochemical attributes in both Cambisols and Vertisols. Several soil attributes altered as a result of cropping compared to those of the adjoining grassland and forestland. For instance, long-term continuous cultivation had a significant negative effect on soil quality due to significant increase in soil salinity and alkalinity [pH, EC, SAR, exchangeable $\mathrm{Na}$, and ESP] and decrease in SOC, $\mathrm{N}$ total, available $\mathrm{P}$ and $\mathrm{K}$, exchangeable cations ( $\mathrm{Ca}, \mathrm{Mg}$, and $\mathrm{K})$, and CEC. In contrary, soils under forest and grassland by increasing the $\mathrm{OC}$ input and improving the fertility parameters and physical conditions led to decline runoff and erosion thereby controlling soil deterioration. In cultivated area, most of the evaluated chemical attributes (such as $\mathrm{pH}, \mathrm{EC}, \mathrm{SOC}, \mathrm{CCE}$, total N, and CEC) showed a significant change $(P \leq 0.05)$ than that of forestland. Overall, loss of soil organic matter and increase in salinity were known as the major problems in relation to long-term continuous cultivation. Soils under continuous cultivation through changes in soil organic matter and $\mathrm{pH}$ (mainly in the Cambisols area) showed a decline of 9-17\% in SQI compared to those of the adjacent soils under grassland and forest.

Acknowledgments This study was a part of the student projects in BS period as well as a national research project. The authors gratefully acknowledge Urmia University and the Iran National Science Foundation for the financial support of this research project.

Open Access This article is distributed under the terms of the Creative Commons Attribution License which permits any use, distribution, and reproduction in any medium, provided the original author(s) and the source are credited.

\section{References}

Abbasi MK, Zafar M, Razaq Khan S (2007) Influence of different land-cover types on the changes of selected soil properties in the mountain region of Rawalakot Azad Jammu and Kashmir. Nutr Cycle Agroecosyst 78:97-110

Ahuja LR (2003) Quantifying agricultural management effects on soil properties and processes. Geoderma 116:1-2 
Amacher MC, O’Neill KP, Perry CH (2007) Soil vital signs: A new Soil Quality Index (SQI) for assessing forest soil health. Research Paper RMRS-RP-65WWW. Fort Collins, CO: U.S. Department of Agriculture, Forest Service, Rocky Mountain Research Station

Barre P, Velde B, Abbadie L (2007) Dynamic role of "illite-like" clay minerals in temperate soils: facts and hypothesis. Biogeochemistry 82:77-88

Barre P, Berger G, Velde B (2009) How element translocation by plants may stabilize illitic clays in the surface of temperate soils. Geoderma 151:22-30

Başaran M, Erpul G, Tercan AE, Çanga MR (2008) The effects of land use changes on some soil properties in İndağ Pass-Çankırı, Turkey. Environ Monit Assess 136:101-119

Biscaye PE (1965) Mineralogy and sedimentation of recent deep sea clay in the Atlantic Ocean and adjacent seas and oceans. Geo Soc Am Bull 76:803-832

Bowman RA, Reeder JD, Lober RW (1990) Changes in soil properties in a Central Plains rangeland soil after 3, 20 and 60 years of cultivation. Soil Sci 150:851-857

Brady NC, Weil RR (1999) The nature and properties of soils. Prentice-Hall, Inc, New Jersey

Chapman HD (1965) Cation exchange capacity. In: Black CA (ed) Methods of soil analysis, Part 2. ASA-SSSA, Madison, pp 891-900

Corwing DL, Kaffka SR, Hopmans JW, Mori Y, Van Groenigen JW, Van Kessel C, Lesch SM, Oster JD (2003) Assessment and fieldscale mapping of soil quality properties of a saline-sodic soil. Geoderma 114:231-259

Cotching WE, Kidd DB (2010) Soil quality evaluation and the interaction with land use and soil order in Tasmania, Australia. Agric Ecosyst Environ 137:358-366

Day PR (1966) Particle fractionation and particle-size analysis. In: Black CA (ed) Methods of soil analysis. Part I. ASA-SSSA, Madison, pp 545-566

De la Rosa D, Sobral R (2008) Soil quality and methods for its assessment. In: Braimoh AK, Vlek PLG (eds) Land Use and Soil Resources. Springer Science + Business Media B.V, Dordrecht, pp 167-200

Dixon JB, Schulz DJ (2002) Soil mineralogy with environmental applications. Soil Science Society of America, Madison

Du Toit ME, Du Preez CC, Hensley M, Bennie ATP (1994) Effect of cultivation on the organic matter content of selected dryland soils in South Africa. South Afr J Plant Soil 11:71-79

FAO/ISRIC/ISSS (2006) World Reference Base for Soil Resources (WRB). Food and agriculture organization of the United Nations. World Soil Resources reports no. 103. ISRIC and ISSS, Rome, Italy

Graham RC, O'Geen AT (2010) Soil mineralogy trends in California landscapes. Geoderma 154:418-437

Guo LB, Gifford RM (2002) Soil carbon stocks and land use change: a meta analysis. Glob Change Biol 8:345-360

Hajabbasi MA, Jalalian A, Karimzadeh R (1997) Deforestation effects on soil physical and chemical properties, Lordegan, Iran. Plant Soil 190:301-308

Hein JR, Dowling JS, Schuetze A, Lee HJ (2003) Clay-minerals suites, sources, and inferred dispersal routes: Southern California continental shelf. Marine Environ Res 56:79-102

Hontoria C, Rodriguez-Murillo JC, Saa A (1999) Relationships between soil organic carbon and site characteristics in Peninsular Spain. Soil Sci Soc Am J 63:614-621

Kamprath EJ (1999) Soil fertility and plant nutrition. In: Sumner ME (ed) Handbook of soil science. CRC press, Washington, DC, pp D-1-D-186

Kettler TA, Lyon DJ, Doran JW, Powers WL, Stroup WW (2000) Soil quality assessment after weed-control tillage in a no-till wheatfollow cropping system. Soil Sci Soc Am J 64:339-346
Khormali F, Abtahi A (2003) Origin and distribution of clay minerals in calcareous arid and semi-arid soils of Fars province, south Iran. Clay Miner 38:511-527

Kong X, Zhang F, Wei Q, Xu Y, Hui J (2006) Influence of land use change on soil nutrients in an intensive agricultural region of North China. Soil Till Res 88:85-94

Kunze GW (1965) Pretreatment for mineralogical analysis. In: Klute A (ed) Methods of soil analysis. Part I. ASA-SSSA, Madison, pp 210-221

Liu SL, Fu BJ, Lu YH, Chen LD (2002) Effects of reforestation and deforestation on soil properties in humid mountainous areas: a case study in Wolong Nature Reserve, Sichuan province, China. Soil Use Manag 18:376-380

Mehra OP, Jackson ML (1960) Iron oxide removal from soils and clays by a dithionite citrate system with sodium bicarbonate. Clays Clay Miner 7:317-327

Nelson RE (1982) Carbonate and gypsum. In: Page AL (ed) Methods of soil analysis, Part 2. ASA-SSSA, Madison, pp 181-199

Nelson DW, Sommers LE (1982) Total carbon, organic carbon, and organic matter. In: Page AL (ed) Methods of soil analysis, Part 2. ASA-SSSA, Madison, pp 539-580

Nelson DW, Sommers LE (1998) Total nitrogen analysis for soil and plant tissues. J Assoc Off Anal Chem 63:770-778

Ni SJ, Zhang JH (2007) Variation of chemical properties as affected by soil erosion on hill slopes and terraces. Euro J Soil Sci 58:1285-1292

Olsen SR, Sommers LE (1982) Phosphorus. In: Page Al, Miller RH, Keeney DR (eds) Methods of soil analysis. Part. ASA-SSSA, Madison, pp 403-430

Pal DK, Srivastava P, Bhattacharyya T (2003) Clay illuviation in calcareous soils of the semi-arid part of the Indo-Gangetic Plains, India. Geoderma 115:177-192

Quiroga AR, Buschaiazzo AF, Peinemann N (1996) Soil organic matter particle fractions in soils of semi-arid Argentinean pampas. Soil Sci 161:104-107

Rezapour S, Samadi A (2012) Assessment of inceptisols soil quality following long-term cropping in a calcareous environment. Environ Monit Assess 184:1311-1323

Rezapour S, Jafarzadeh AA, Samadi A, Oustan SH (2009) Impacts of clay mineralogy and physiographic units on the distribution of potassium forms in calcareous soils in Iran. Clay Miner 44:329-339

Rezapour S, Samadi A, Khodaverdiloo H (2012) Impact of long-term wastewater irrigation on variability of soil attributes along a landscape in semi-arid region of Iran. Environ Earth Sci 67:1713-1723

Robinson DA, Phillips CP (2001) Crust development in relation to vegetation and agricultural practice on erosion susceptible, dispersive clay soil from central and southern Italy. Soil Till Res 60:1-9

Rubio A, Escudero A (2005) Effect of climate and physiography on occurrence and intensity of decarbonation in Mediterranean forest soils of Spain. Geoderma 125:309-319

Salinity Laboratory Staff (1954) Diagnosis and improvement of saline and alkali soils. Agriculture Handbook, vol. 60. U. S. Department of Agriculture, Washington, DC

Smith JL, Doran JW (1996) Measurements and use of $\mathrm{pH}$ and electrical conductivity for soil quality analysis. In: Methods for Assessing Soil Quality, SSSA Special Publication 49. SSSA, Madison, pp 169-185

Soil Survey Staff (2010) Keys to Soil Taxonomy. U. S. Department of Agriculture, Natural Resources Conservation Service, Washington, DC

Solomon D, Lehmann J, Zech W (2000) Land use effects on soil organic matter properties of chromic luvisols in semi-arid northern Tanzania: carbon, nitrogen, lignin and carbohydrates. Agric Ecosyst Environ 78:203-213 
SPSS 15 (2006) Microsoft windows. SPSS Inc, Chicago

Srinivasarao CH, Vittal K, Tiwari KN, Gajbhiye PN, Kundu SU (2007) Categorisation of soils based on potassium reserves and production system: implications in K management. Aust J Soil Res 45:438-447

Stolt MH, Baker JC, Simpson TW (1993) Soil-landscape relationships in Virginia: II. Reconstruction analysis and soil genesis. Soil Sci Soc Am J 57:422-428

Thomas GW (1982) Exchangeable cations. In: Page Al, Miller RH, Keeney DR (eds) Methods of soil analysis. Part. ASA-SSSA, Madison, pp 159-166

Wang D, Anderson DW (1998) Stable Carbon Isotopes of Carbonate Pendants from Chernozemic Soils of Saskatchewan, Canada. Geoderma 84:309-322

Wang J, Fu B, Qiu Y, Chen L (2001) Soil nutrients in relation to land use and landscape position in the semi-arid small catchment on the loess plateau in China. J Arid Environ 48:537-550
Xiaohong Ch, Zhenghu D (2009) Changes in soil physical and chemical properties during reversal of desertification in Yanchi County of Ningxia Hui Autonomous region, China. Envrion Geol 57:975-985

Yu W, Zhao SH, Zhang L, Shen SH, Ma Q (2005) The relation between the content of organic phosphorus and latitude in northeast China phaeozem. Biol Fertil Soils 42:159-162

Zhao WZ, Xiao HL, Liu ZM, Li J (2005) Soil degradation and restoration as affected by land use change in the semiarid Bashang area, northern China. Catena 59:173-186

Zhao Y, Xu X, Darilek JL, Huang B, Sun W, Shi X (2009) Spatial variability assessment of soil nutrients in an intense agricultural area, a case study of Rugao County in Yangtze River Delta Region China. Envrion Geol 57:1089-1102

Zucca C, Canu A, Previtali F (2010) Soil degradation by land use change in an agropastoral area in Sardinia (Italy). Catena $83: 46-54$ 